\title{
New iodine derivatives of flavonol and isoflavone
}

\author{
MÁRIO G. DE CARVALHO ${ }^{1}$, VIRGINiA C. DA SILVA ${ }^{1}$, TÂNIA M.S. DA SILVA ${ }^{1,2}$, \\ CELSO A. CAMARA ${ }^{3}$ and RAIMUNDO BRAZ-FILHO ${ }^{1,4}$ \\ ${ }^{1}$ Departamento de Química, ICE, Universidade Federal Rural do Rio de Janeiro, BR-465 km 07 \\ 23890-000 Seropédica, RJ, Brasil \\ ${ }^{2}$ Núcleo Complexo Produtivo de Saúde, IMS-CAT-UFBA, Av. Olívia Flores, 3.000, Candeias \\ 45055-090 Vitória da Conquista, BA, Brasil \\ ${ }^{3}$ Departamento de Química, Universidade Federal Rural de Pernambuco, Rua Dom Manoel de Medeiros s/n \\ Dois Irmãos, 52171-900 Recife, PE, Brasil \\ ${ }^{4}$ Setor de Química de Produtos Naturais, LCQUI-CCT, Universidade Estadual Norte Fluminense Darcy Ribeiro (UENF) \\ 28013-602 Campos, RJ, Brasil \\ Manuscript received on November 19, 2007; accepted for publication on November 4, 2008, \\ contributed by RAIMUNDO BRAZ-FILHO*
}

\begin{abstract}
The reaction of the flavonol 3,7,3', $4^{\prime}$-tetra- $O$-methylquercetin (1) and of the isoflavone $7,4^{\prime}$-di- $O$-methylgenistein (2) with alkaline iodine in methanol afforded four new iodine derivatives: 8-iodo-5-hydroxy-3,7,3' $4^{\prime}$-tetramethoxyflavone (1a) and 6-iodo-5-hydroxy-3,7,3', 4'-tetramethoxyflavone (1b) from 1; 2 afforded a mixture of two compounds, identified as a racemic mixture of $( \pm)$-trans-5-hydroxy-2,3,7,4'-tetramethoxy-8-iodo-isoflavanone (2a) and ( \pm )-trans-5-hydroxy-2,3,7,4'-tetramethoxy-6,8-diiodo-isoflavanone $(\mathbf{2 b})$. The formation of these different products reveals a significant difference involving the chemical interaction between the reactive site of $\alpha, \beta$-unsaturated ketones of flavonol and isoflavone under the tested reaction conditions (using $\mathrm{I}_{2} / \mathrm{KOH} / \mathrm{MeOH}$ ). Furthermore, the trans stereoselectivity is noteworthy in the nucleophylic addition of methanol at the isoflavone $\alpha, \beta$-unsaturated system. The structures were identified on the basis of spectral data, mainly 1D and 2D NMR and mass spectra.
\end{abstract}

Key words: flavonol, isoflavone, iodoflavonoid, iodoisoflavonoid, iodine derivatives.

\section{INTRODUCTION}

In previous reports we have described the isolation and identification of natural flavonoids in Solanaceae (Silva 2002, Silva et al. 2004) and Leguminosae (Silva et al. 2006, 2007), preparation of some derivatives and made the unambiguous proton and carbon- 13 chemical shifts assignments (Carvalho et al. 2006). Citations concerning the synthesis (Guo-Qiang and Zhong 1997, Zembower and Zhang 1998, Quintin and Lewing, 2004, Bekker et al. 1998) and biological importance of flavonoids and biflavonoids besides incorporation of any

\footnotetext{
* Member Academia Brasileira de Ciências Correspondence to: Mário Geraldo de Carvalho E-mail: mgeraldo@ufrrj.br
}

groups to improve those activities have been frequently observed (Dejjermm 1997, Paulo and Mota-Filipe 2006). The iodination of natural flavones is a procedure that has been used to obtain some useful intermediates in the synthesis of biflavonoids (Zheng et al. 2004, Ali and Ilyas 1986).

Halogenated derivatives of natural flavonoids are relatively rare in the literature, particularly with the iodine derivate, whose synthetic utility is largely due to the increase in reactivity of this particular halogen, as in nucleophilic aromatic substitutions (Yaipakdee and Robertson 2001). Iodine derivatives are described in the synthesis of biflavonoids, by using expensive reagents difficult to obtain (Rho et al. 2001, Bovicelli et al. 2001). 
<smiles>COc1cc(O)c2c(=O)c(OC)c(-c3ccc(OC)c(OC)c3)oc2c1</smiles><smiles>[R]c1c(O)c([R])c2c(=O)c(OC)c(-c3ccc(OC)c(OC)c3)oc2c1[R]</smiles>

$74 \%$ as a mixture<smiles>COc1ccc(-c2coc3cc(OC)cc(O)c3c2=O)cc1</smiles><smiles>[R]c1ccc([C@]2(OC)C(=O)c3c(O)c([R])c(OC)c([R])c3OC2OC)cc1</smiles>

$$
\begin{aligned}
& (+/-) \mathbf{2 a} R=H, R^{1}=I \\
& (+/-) \mathbf{2 b} R=R^{1}=I \\
& 85 \% \text { as a mixture }
\end{aligned}
$$

Fig. 1 - Structure and reactions of flavonoids $\mathbf{1}$ and $\mathbf{2}$.

In this paper we describe the first iodination reaction of two flavonoids (Fig. 1), the flavonol quercetin $3,7,3^{\prime}, 4^{\prime}$-tetramethyl ether $\left(\mathbf{1}, 3,7,3^{\prime}, 4^{\prime}\right.$-tetra- $O$-methylquercetin, retusin) isolated from Solanum species (Silva 2002, Silva et al. 2004) and the isoflavone 7,4'-di- $O$ methylgenistein (2, 5-hydroxy-4', 7-dimethoxyisoflavone) obtained by selective methylation of bichanin A (5,7dihydroxy-4'-methoxyisoflavone) isolated from Andira species (Silva et al. 2006, 2007), using iodine as an inexpensive and easily available reagent. These flavonoids have C-6 or C-8 positions as two sites for electrophylic substitutions. The functionality of similar nucleus in synthesis of bichalcones and other biflavonoids have been reported (Ali and Ilyas 1986). This work led us to synthesize four new iodine derivatives: 5-hydroxy8-iodo-3,7,3', 4'-tetramethoxyflavone (1a) and the C-6 corresponding regioisomer (1b) from $\mathbf{1}$ in $74 \%$ yield and 2 afforded a mixture constituted by $( \pm)$-trans-5hydroxy-2,3,7,4'-tetramethoxy-8-iodo-isoflavanone (2a) and ( \pm )-trans-5-hydroxy-2,3,7,4'-tetramethoxy-6,8-diiodo-isoflavanone (2b) in $85 \%$ yield. The products structures were identified on the basis of spectral data, mainly 1D and 2D NMR and mass spectra. The 1D and 2D NMR spectra were also used to the complete ${ }^{1} \mathrm{H}$ and ${ }^{13} \mathrm{C}$ chemical shift assignments of the four new products. These new derivatives of natural flavonoids, 1a, 1b, 2a and $\mathbf{2 b}$, can be used as intermediate in synthetic procedure and to include useful group to study the mechanism of flavonoids biological activity.

\section{MATERIALS AND METHODS}

\section{General Experimental Procedure}

NMR: Bruker DRX-500 (500 MHz for ${ }^{1} \mathrm{H}$ and $125 \mathrm{MHz}$ for ${ }^{13} \mathrm{C}$ ) and Bruker AMX-300 (300 MHz for ${ }^{1} \mathrm{H}$ and $75 \mathrm{MHz}$ for ${ }^{13} \mathrm{C}$ ) were used to obtain the $1 \mathrm{D}$ and $2 \mathrm{D}$ ${ }^{1} \mathrm{H}$ and ${ }^{13} \mathrm{C}$ NMR spectra and Bruker AC-200 was used to make the NOEDIFF experiments, in $\mathrm{CDCl}_{3}$ as sol- 


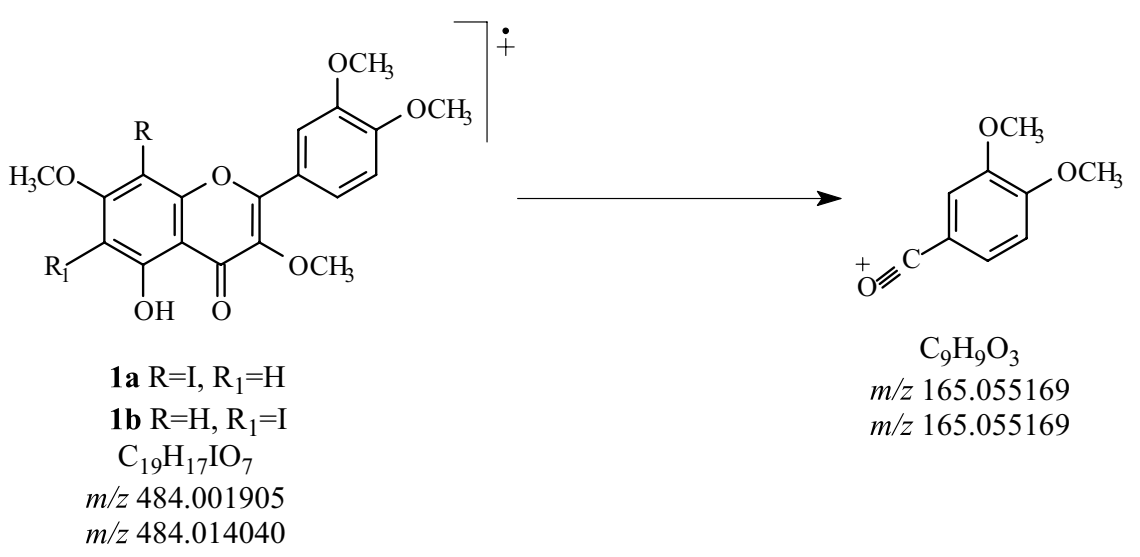

Fig. 2 - Proposed fragmentation patterns for $\mathbf{1 a} \mathbf{a} \mathbf{1} \mathbf{b}$ derivatives based on the HREIMS.

vent and the signals at $\delta_{H} 7.24\left(\mathrm{CHCl}_{3}\right)$ and $\delta_{C} 77.00$ $\left(\mathrm{CDCl}_{3}\right)$ as internal standards. The LRMS were obtained on a GC-MS Varian Saturn 2000 with ion trap and IE ionization, at $70 \mathrm{eV}$. The HRESI-MS were recorded on a VG 7070E-HF spectrometer using methanol: $\mathrm{H}_{2} \mathrm{O}$, $\mathrm{Ar}$ as CAD, DE $20 \mathrm{eV}$ for MS and $45 \mathrm{eV}$ for MS-MS using methanol: $\mathrm{H}_{2} \mathrm{O} /$ formic acid in positive mode. The reactions were monitored by aluminum-backed silica gel TLC plates and visualized under UV $\left(\lambda_{\max } 254 \mathrm{~nm}\right)$ or using $1 \% \mathrm{AlCl}_{3}$ in ethanol as revealing spray solution.

\section{SYNTHESIS OF THE COMPOUNDS}

Derivative 2 (Fig. 1) was prepared by treating a methanol solution of biochanin A (4'-O-methylgenistein, $50.0 \mathrm{mg})$ with ethereal diazomethane solution followed by solvent evaporation (Silva et al. 2006, 2007). The natural flavonoid 1 (Fig. 1) (Silva 2002) (20.0 mg, $0.056 \mathrm{mMol}$ ) and derivative 2 (28.0 mg, $0.093 \mathrm{mMol}$ ), were dissolved in $10 \mathrm{~mL}$ of methanol, mixed with potassium hydroxide (25.0 $\mathrm{mg}$ in each reaction), under continuous stirring, and to this mixture iodine was added in small portions to slight excess. The solutions were kept at room temperature under stirring for $3 \mathrm{~h}$. Aliquots of the reaction mixture were periodically analyzed by TLC until complete reaction. The organic solvents were removed under reduced pressure, and the remaining aqueous solution was extracted with dichloromethane $(3 \times 15 \mathrm{~mL})$. The combined organic solutions were dried with anhydrous sodium sulfate and the solvent was evaporated under reduced pressure. Reaction of 1 (Fig. 1) yielded a brownyellowish gum $(\mathbf{1 a}+\mathbf{1 b}, 20.0 \mathrm{mg}, 74 \%)$ and the reaction of 2 (Figs. 1 and 3 ) yielded a yellow gum as a mixture of $2 \mathbf{a}$ and $\mathbf{2 b}(23.8 \mathrm{mg}, 85 \%)$.

\section{RESULTS AND DISCUSSION}

The flavonoid 3,7,3', 4'-tetramethylquercetin (1) afforded a mixture of 8-iodo-3,7,3', $4^{\prime}$-tetramethylquercetin (1a) and 6-iodo-3,7,3', $4^{\prime}$-tetramethylquercetin (1b) in a 3(1a):1(1b) ration, as determined by inspection of ${ }^{1} \mathrm{H}$ NMR data. The reaction afforded a mixture of regioisomers $\mathbf{1 a}$ and $\mathbf{1 b}$ involving the C-8 and C-6 positions, respectively, reflecting the higher reactivity of the C-8 position under the experimental conditions (Fig. 1). The HREIMS of $\mathbf{1 a}$ and $\mathbf{1 b}$ mixture gave $[\mathrm{M}]^{+}$at $m / z 484.01404$ corresponding to the molecular formula $\mathrm{C}_{19} \mathrm{H}_{17} \mathrm{IO}_{7}$ (Calcd. for $\mathrm{C}_{19} \mathrm{H}_{17} \mathrm{IO}_{7} \mathrm{~m} / z$ 484.00190). From the molecular ion $\mathrm{m} / z 484.014040$ was obtained a fragment of $m / z 165.055169$ as base peak corresponding to the fragment involving the Bring (Fig. 2).

The ${ }^{1} \mathrm{H}$ NMR spectrum of $\mathbf{1 a} / \mathbf{1} \mathbf{b}$ mixture showed signals of 1a (component present in major proportion) in the aromatic region corresponding to four hydrogen atoms and the hydrogen-bonded absorption at $\delta_{H} 12.92$ $(s)$ of hydroxyl group at C-5. The singlet at $\delta_{H} 6.42$ was attributed to H-6 at A-ring. The chemical shifts, the multiplicity and the coupling constants values $(J)$ of the signals in $\delta_{H} 8.06\left(d d, J=1.8\right.$ and $\left.8.7 \mathrm{~Hz}, \mathrm{H}-6^{\prime}\right), \delta_{H}$ $7.98\left(d, J=1.8 \mathrm{~Hz}, \mathrm{H}-2^{\prime}\right)$, and $7.03\left(d, J=8.7 \mathrm{~Hz}, \mathrm{H}-5^{\prime}\right)$ allowed to recognize the $\mathrm{ABC}$ system of $\mathrm{B}$-ring with substitutions in the positions $3^{\prime}$ and $4^{\prime}$ (Table I). The $2 \mathrm{D}^{1} \mathrm{H}$ ${ }^{1} \mathrm{H}$-COSY confirmed the interactions spin-spin for these 

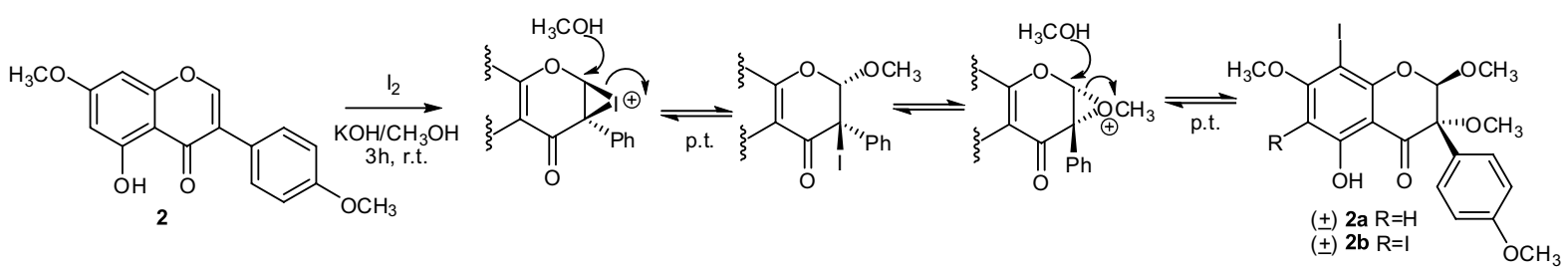

Fig. 3 - Proposed pathway to the observed trans stereochemistry in isoflavone iodination.

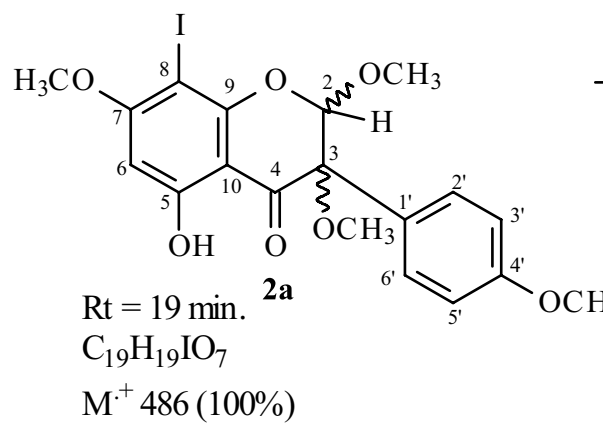

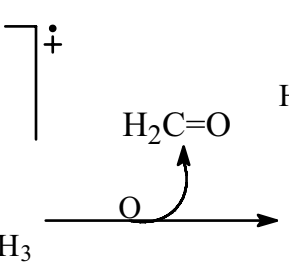

$\mathrm{C}_{19} \mathrm{H}_{19} \mathrm{IO}_{7}$ $\mathrm{M}^{+} 486(100 \%)$<smiles>[R20]C1CC2(c3ccc(OC)cc3)C([R])Oc3c(I)c(OC)cc(O)c3C(=O)C12[R]</smiles>

$\mathrm{R}, \mathrm{R}_{1}=\mathrm{H}, \mathrm{OMe}$ $\mathrm{m} / \mathrm{z} 456(40 \%)$

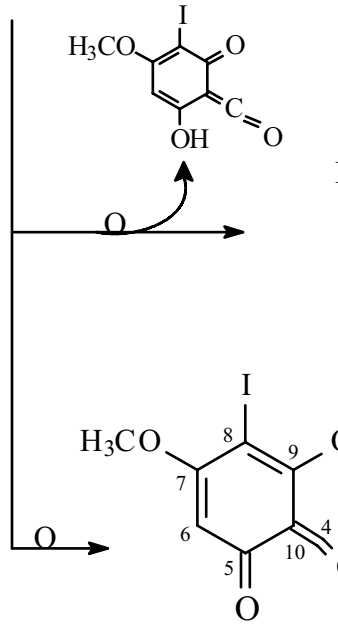<smiles>CO/C=C(/OC)c1ccc(OC)cc1</smiles>

$\mathrm{m} / \mathrm{z} 194(90 \%)$<smiles>COc1ccc(C(=O)C=O)cc1</smiles>

$m / z 179(40 \%)$

Fig. 4 - Proposed fragmentation patterns for 2a (only peaks classified as principals).

hydrogen atoms. These data and the singlet between 3.91-4.0 ppm corresponding to four methoxyl groups allowed us to characterize the product as a 5-hidroxytetramethoxy-flavonol. The ${ }^{13} \mathrm{C}$ NMR-PENDANT spectrum revealed signals for nineteen carbons, being four methynes, four methoxyl groups, and eleven quarternary carbon atoms. The $2 \mathrm{D}{ }^{1} \mathrm{H}^{-13} \mathrm{C}-\mathrm{COSY}-{ }^{1} J_{\mathrm{CH}}$ (HMQC) spectrum was used to recognize the direct correlations $\left({ }^{1} \mathrm{~J}_{\mathrm{CH}}\right)$ of the hydrogen and carbon atoms corresponding to methynes and methoxyl groups (Table I). The correct position of methyne carbons was confirmed by heteronuclear interactions at long range $\left({ }^{2} J_{C H}\right.$ and $\left.{ }^{3} J_{C H}\right)$ of the
C-5 $\left(\delta_{C} 163.34\right), \mathrm{C}-7$ ( $\left.\delta_{C} 163.99\right), \mathrm{C}-8\left(\delta_{C} 60.98\right)$, and C-10 $\left(\delta_{C} 106.15\right)$ with H-6 $\left(\delta_{H} 6.42\right)$. The heteronuclear interactions of OH-5 $\left(\delta_{H} 12.92\right)$ with both C-5 $\left(\delta_{C}\right.$ $\left.163.34,{ }^{2} J_{C H}\right)$ and CH-6 $\left(\delta_{C} 95.45,{ }^{3} J_{C H}\right)$ were used to characterize definitively the 1a structure. Other correlations revealed by HMBC are shown in Table I. The iodine derivative $\mathbf{1 b}$ was also characterized by same procedure, which revealed the data described in Table I.

However, the same reaction using the isoflavone (2) yielded different products when compared with those obtained of flavonol $\mathbf{1}$, by the presence of two additional methoxyl groups located at $\mathrm{CH}-2$ and $\mathrm{C}-3$ of the enone 


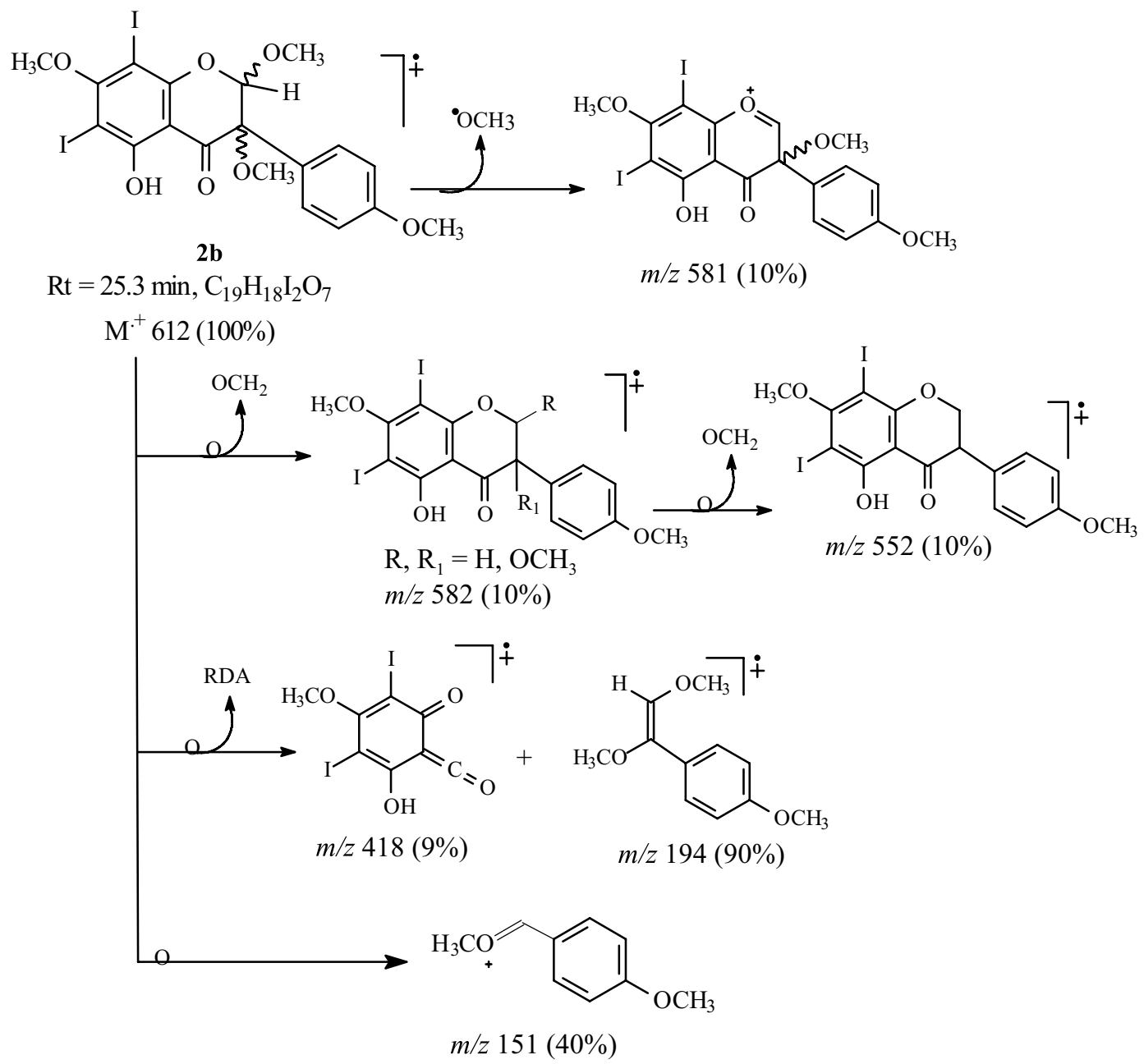

Fig. 5 - Proposed fragmentation patterns for $\mathbf{2 b}$ (only peaks classified as principals).

system (Figs. 1 and 3). The CG-LREIMS of the mixture containing the compounds $\mathbf{2} \mathbf{a}$ and $\mathbf{2 b}$ showed two peaks $\left[\mathrm{T}_{R} 19.0 \mathrm{~min}(58.14 \%)\right.$ and $\left.\mathrm{T}_{R} 25.3(41.86 \%)\right]$ and the corresponding molecular ions peaks identified at $m / z 486(100 \%, 2 \mathbf{a})$ and $612(100 \%, 2 b)$, as summarized in Figures 4 and 5. Besides these data, the analysis of ${ }^{1} \mathrm{H}$ and ${ }^{13} \mathrm{C}$ NMR let us to identify the chemical shifts represented by two close values (Table I), suggesting similar structures compatible with the presence of these two enantiomeric pairs ( $\mathbf{2} \mathbf{a}$ and $\mathbf{2 b}$ ). The detailed mass spectral data analysis and the NOEDIFF experiments justified both similar structures with two additional methoxyl groups with one and two incorporated iodine in $\mathbf{2} \mathbf{a}$ and $\mathbf{2} \mathbf{b}$, respectively. These structures and locations of those groups were recognized by analysis of additional peaks in the mass spectra $m / z(\%)$ : 2a: 486 (100, $\mathrm{C}_{19} \mathrm{H}_{19} \mathrm{O}_{7} \mathrm{I}$ ); 456 (40, M-30), 194 (90), 179 (40), 151 (25) Figure 4; 2b: $m / z 612\left(100, \mathrm{C}_{19} \mathrm{H}_{18} \mathrm{O}_{7} \mathrm{I}_{2}\right), 582$ (10), 552 (10), 418 (9), 194 (90), 151 (40); been 194 $=\mathrm{H}_{3} \mathrm{COCH}=\mathrm{COCH}_{3}\left(\mathrm{C}_{6} \mathrm{H}_{4}-\mathrm{OCH}_{3}\right)$ by RDA, Figure 5 . The data of ${ }^{1} \mathrm{H}$ and ${ }^{13} \mathrm{C}$ NMR $\left(\left\{{ }^{1} \mathrm{H}\right\}\right.$ and DEPT) 1D- and $2 \mathrm{D}\left({ }^{1} \mathrm{Hx}^{1} \mathrm{H}-\mathrm{COSY}, \mathrm{HMQC}\right.$ and HMBC) spectra analysis are described in Table I. The NOEDIFF experiments were also used to confirm these structures, contributing to complete ${ }^{1} \mathrm{H}$ and ${ }^{13} \mathrm{C}$ NMR assignments (Table I) and to identify the relative configuration of C-2 and C-3. The irradiations at $\delta_{H} 3.63\left(\mathrm{H}_{3} \mathrm{CO}-2, \mathbf{2 a}\right.$ and $\left.\mathbf{2 b}\right)$ yield NOE at H-2 [5.22 (2a) and $\left.\delta_{H} 5.18(\mathbf{2 b})\right]$, irradiation at $3.19\left(\mathrm{H}_{3} \mathrm{CO}-3, \mathbf{2 b}\right)$ yield $\mathrm{NOE}$ at $\mathrm{H}-2\left(\delta_{H} 5.18\right.$, 2b), HO-5 $\left(\delta_{H} 12.17\right)$ and at $\mathrm{H}-2^{\prime}, \sigma^{\prime}\left(\delta_{H} 7.42\right)$; irradi- 
MÁRIO G. DE CARVALHO et al.

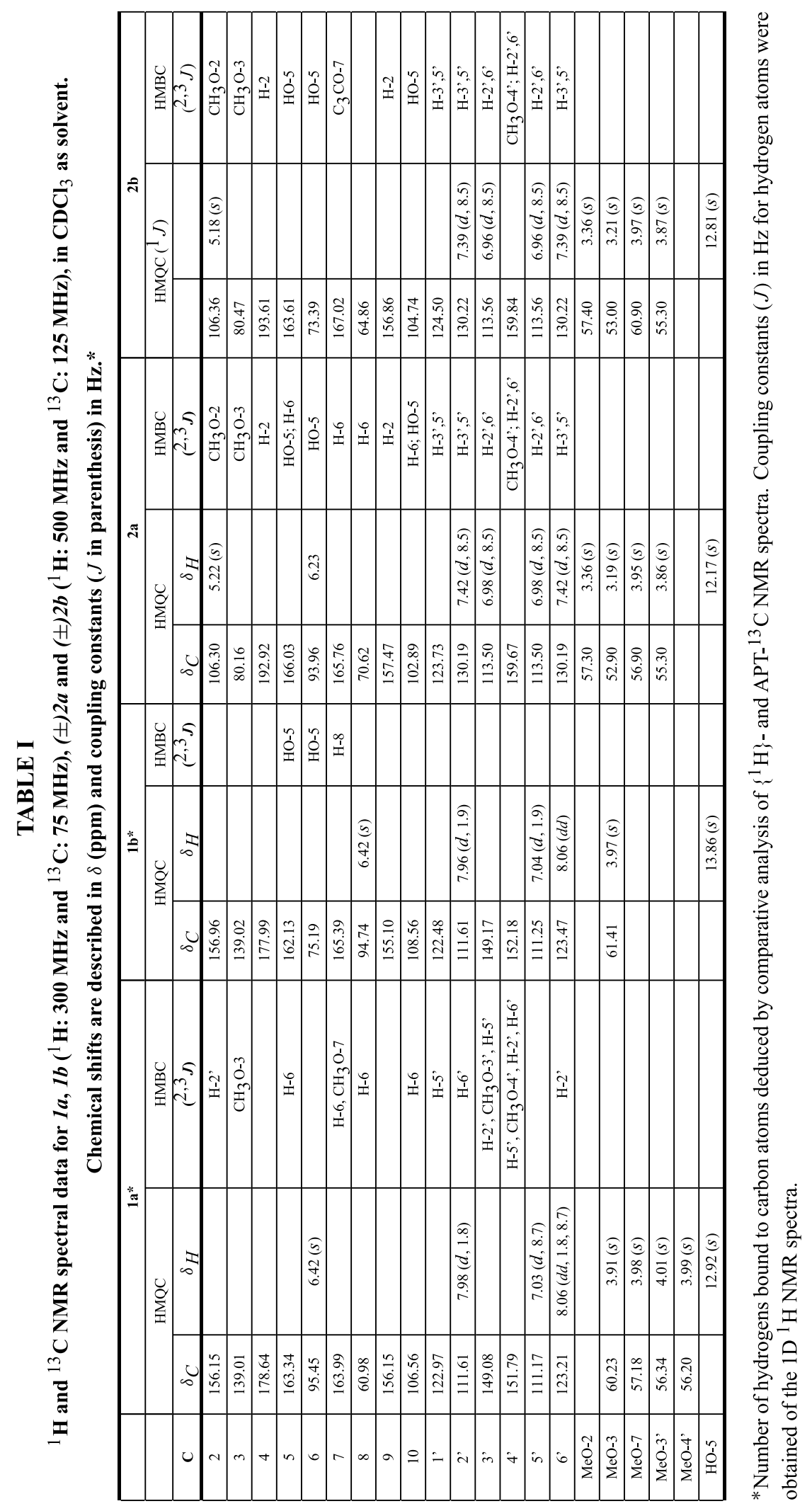


ation at $\delta_{H} 3.86\left(\mathrm{H}_{3} \mathrm{CO}-4^{\prime \prime}\right.$ of $\left.\mathbf{2 a}\right)$ yielded $\mathrm{NOE}$ at $\delta_{H}$ $6.98\left(\mathrm{H}-3^{\prime}, 5^{\prime}\right)$ and at $\delta_{H} 3.95\left(\mathrm{H}_{3} \mathrm{CO}-7\right.$ of $\left.2 \mathbf{2 a}\right)$ yielded $\mathrm{NOE}$ at $6.23(\mathrm{H}-6)$; irradiation at $\delta_{H} 3.21\left(\mathrm{H}_{3} \mathrm{CO}-3,2 \mathrm{a}\right)$ yield NOE at $\delta_{H} 5.22(\mathrm{H}-2), \delta_{H} 7.39\left(\mathrm{H}-2^{\prime}, 6^{\prime}\right)$ and HO$5\left(\delta_{H} 12.81\right)$; no signal was observed in the spectrum obtained from irradiation at $\delta_{H} 3.97\left(\mathrm{H}_{3} \mathrm{CO}-7\right.$ of $\left.\mathbf{2 b}\right)$; on the other hand a doublet at $\delta_{H} 6.96\left(\mathrm{H}-3^{\prime}, 5^{\prime}\right)$ was observed in the spectrum obtained by irradiation at $\delta_{H}$ $3.87\left(\mathrm{H}_{3} \mathrm{CO}-4^{\prime}\right.$ of $\left.\mathbf{2 b}\right)$. Thus the NOE observed at $\mathrm{H}-2$ and $\mathrm{H}-3$ with irradiation at the $\mathrm{H}_{3} \mathrm{CO}-2$ was used to justify the trans correlation relationship between methoxyl groups at 2 and 3 positions, according to the proposed mechanism summarized in Figure 3. The detailed analysis of ${ }^{1} \mathrm{H}$ and ${ }^{13} \mathrm{C}$ NMR (1D and 2D) spectra let us to make the complete data assignments of these new derivatives (Table I).

In this work we rationalize trans stereoselectivity observed at the $\alpha, \beta$-enone system of $\mathbf{2}$ as a well established addition of methanol to an intermediate halonium species (Bateman et al. 1983), followed by alkoxide substitution of the resulting $\beta$-alkoxy-(or $\beta$-hydroxy-)$\alpha$-halo derivative intermediate (Bird et al. 1983). Presumably, solvolytic conditions in methanol drives the incipient benzylic carbenium formed to be anchimeric assisted by a methoxy group (Smith et al. 1965), thus explaining the trans selectivity observed in the products. The reactions performed in the present work are of exploratory nature, carried out to ascertain experimental conditions and to ensure the observed products.

As far as we know, this is the first work that describes the incorporation of nuclear iodine atoms in flavonoids $\mathbf{1}$ and $\mathbf{2}$ along with the stereoselective trans incorporation of two methoxyl groups at the 2 and 3 positions of compound $\mathbf{2}$.

\section{ACKNOWLEDGMENTS}

The authors are grateful to Conselho Nacional de Desenvolvimento Científico e Tecnológico (CNPq), Coordenação de Aperfeiçoamento de Pessoal de Nível Superior (CAPES), Fundação Carlos Chagas Filho de Amparo à Pesquisa do Estado do Rio de Janeiro (FAPERJ) and Programa de Apoio Científico e Tecnológico/Financiadora de Estudos e Projetos (PADCT/FINEP) for fellowships and financial support. We also thank Centro Nordestino de Aplicação e Uso da Ressonância Magnética Nuclear
(CENAUREMN) for the $500 \mathrm{MHz}$ NMR spectra and Instituto de Química - Universidade Federal do Rio de Janeiro (IQ-UFRJ) for the $300 \mathrm{MHz}$ NMR spectra.

\section{RESUMO}

A reação do flavonol 3,7,3', $4^{\prime}$-tetra- $O$-metilquercetina (1) e da isoflavona 7,4' -di- $O$-metilgenisteina (2) com iodo/KOH em metanol forneceu como produto quatro derivados iodados: 8 iodo-5-hidroxi-3,7,3' , 4' -tetrametoxiflavona (1a) e 6-iodo-5hidroxi-3,7,3' , 4'-tetrametoxiflavona (1b) a partir da iodação de 1; a partir de 2 foi obtida uma mistura racêmica composta de ( \pm )-trans-5-hidroxi-2,3,7,4' -tetrametoxi-8-iodo-isoflavanona (2a) e ( \pm -trans-5-hidroxi-2,3,7,4' -tetrametoxi-6,8-diiodoisoflavanona (2b). A formação destes diferentes produtos revela a significante diferença envolvendo a interação química entre o sitio reativo de cetonas $\alpha, \beta$-insaturadas de flavonol e de isoflavonas nas condições experimentais testadas (usando $\mathrm{I}_{2} / \mathrm{KOH} / \mathrm{MeOH}$ ). Além disso, ressalta-se a estereosseletividade trans na adição de metanol ao sistema $\alpha, \beta$-insaturado da isoflavona. As estruturas foram identificadas com análise nos dados espectrométricos de RMN 1D e 2D e massas.

Palavras-chave: flavonol, isoflavona, iodoflavonóide, iodoisoflavonóide, derivados de iodo.

\section{REFERENCES}

Ali SM AND Ilyas M. 1986. Biomimetic approach to biflavonoids: oxidative coupling of $2^{\prime}$-hidroxychalcones with $\mathrm{I}_{2}$ in alkaline methanol. J Org Chem 51: 5415-5417.

Bateman G, Brown BR, CAmpbell JB, Cotton CA, Johnson P, MulqueEn P, O’Neill D, ShaW MR, SMith RA AND TROKE JA. 1983. Synthesis and reactions of 4-aryloxy-flavanes. J Chem Soc Perkin Trans 12: 2903-2912.

BeKKer R, BRANDT EV ANd FERreira D. 1998. Structure and Stereochemistry of the first isoflavanone-benzofuranone biflavonoids. Tetrahedron Lett 39: 6407-6410.

BIRD TGC, BROWN BR, STUART IA AND TYRRELL AWR. 1983. Reactions of flav-2-enes and flav-2-en-4-ones (flavones). J Chem Soc Perkin Trans 1: 1831-1846.

Bovicelli P, Mincione E, Antonioletti R, Bernini R AND COLOMBARI M. 2001. Selective halogenation of aromatics by dimethyldioxirane and halogen ions. Synth Commun 31: 2955-2963.

Carvalho MG de, Gomes MS da R, Pereira AHF, DANIEL JF DE S AND SChripsema J. 2006. Carbon13 and proton NMR assignments of a new agathisflavone derivative. Magn Reson Chem 44: 35-37. 
DeJJERMm M. 1997. Flavonoids in Health and Disease. Rice-Evans CA, PACKer L (Eds), New York, USA.

Guo-Qiang L And Zhong M. 1997. The First Enantioselective Synthesis of Optically Pure $(R)$ - and $(S)-5,5^{\prime \prime}$ Dihydroxy-4', $4^{\prime \prime \prime}, 7,7^{\prime \prime}$-tetramethoxy- $8,8^{\prime \prime}$-biflavone and the Reconfirmation of Their Absolute Configuration. Tetrahedron Lett 38: 1087-1090.

Paulo A ANd Mota-Filipe H. 2006. Effects of some natural 5-hydroxy-isoflavones on cultured human endothelial cells in presence and absence of hydrogen peroxide. $\mathrm{J}$ Pharm \& Pharmacol 58: 101-105.

QUINTIN J AND LEWIN G. 2004. Semisynthesis of Linarin, Acacetin, and 6-Iodoapigenin Derivatives from Diosmin. J Nat Prod 67: 1624-1627.

RHo HS, Ko BS AND JU YS. 2001. A facile preparation of 3-haloflavones using hypervalent iodine chemistry. Synth Commun 31: 2101-2106.

SiLva TMS. 2002. Estudo Químico de Espécies de Solanum, Tese de Doutoramento, Universidade Federal Rural do Rio de Janeiro, Brazil, Departamento de Química PPGQO, p. $1-171$.

Silva TMS, Nascimento RJB, CAmara CA, CAstro RN, Braz-Filho R, Agra M de F and Carvalho MG DE. 2004. Distribution of flavonoids and $N$-transcaffeoyl-tyramine in Solanum subg. Leptostemonum. Biochem Syst Ecol 32: 513-516.
Silva VC Da, Alves AN, Santana A de, Carvalho MG DE, Silva SL dA C AND Schripsema J. 2006. Constituintes Fenólicos e Terpenóides Isolados das Raízes de Andira fraxinifolia (FABACEAE). Quim Nova 29: 1184-1186.

Silva VC da, Carvalho MG DE and Silva SL Da C. 2007. Chemical Constituents from Roots of Andira anthelmia (Leguminosae). Rev Latinoamer de Quim 35(12): $13-19$.

Smith MA, Webb, RA And Cline LJ. 1965. The Oxidation of Flavonols by Periodic Acid in Methanol. J Org Chem 30: 995-997.

YAIPAKDEE P AND ROBERTSON LW. 2001. Enzymatic halogenation of flavanones and flavones. Phytochemistry 57: 341-347.

Zembower DE AND Zhang H. 1998. Total synthesis of robustaflavone, a potential anti-hepatitis B agent. J Org Chem 63: 9300-9305.

Zheng X, Meng WD AND QING FL. 2004. Synthesis of gem-difluoromethylenated biflavonoid via the Suzuki coupling reaction. Tetrahedron Lett 45: 8083-8085. 